\title{
Tribological Behavioural of Bio-Oil Extracted from Peel Waste of Musa Aluminata Balbisiana
}

\author{
H. A. Hamid ${ }^{1,2)}$, Ghazali Omar ${ }^{1,3)^{*}}$, N. A. B. Masripan ${ }^{1,4)}$ and R. Hasan ${ }^{1,4)}$ \\ ${ }^{1)}$ Faculty of Mechanical Engineering, Universiti Teknikal Malaysia Melaka, \\ Hang Tuah Jaya, 76100 Durian Tunggal, Melaka, Malaysia. \\ ${ }^{2)}$ Centre for Research and Innovation Management, Universiti Teknikal Malaysia Melaka, \\ Hang Tuah Jaya, 76100 Durian Tunggal, Melaka, Malaysia \\ ${ }^{3)}$ Advanced Manufacturing Centre, Universiti Teknikal Malaysia Melaka, \\ Hang Tuah Jaya, 76100 Durian Tunggal, Melaka, Malaysia \\ ${ }^{4)}$ Centre for Advanced Research on Energy, Universiti Teknikal Malaysia Melaka, \\ Hang Tuah Jaya, 76100 Durian Tunggal, Melaka, Malaysia \\ *Corresponding author: Ghazali Omar (ghazali@utem.edu.my)
}

Manuscript received 24 February 2020; accepted 20 June 2020; published 31 July 2020

\section{Abstract}

The aim of this study is to investigate the effects of applied loads and temperatures on the tribological properties of MBS oil, which is a bio-oil extracted from banana peel waste of Musa Aluminata Balbisiana, MBS. Tribological evaluation of MBS oil was conducted using pin on disc tribometer as per G 99 ASTM standard. In this method, hemisphere pin was loaded against the rotating disc containing the MBS oil . The test was implemented by dropping $2 \mathrm{ml}$ of MBS oil as a lubricating oil on sliding surface at varying loads from 20 to $100 \mathrm{~N}$ at $27^{\circ} \mathrm{C}, 40^{\circ} \mathrm{C}$ and $100^{\circ} \mathrm{C}$. The results showed that, at $80 \mathrm{~N}$, the coefficient of friction (COF), volume wear loss $\left(V_{\text {loss }}\right)$, wear scar diameter (WSD), and wear rate (Ws) values were lower at all the tested temperatures. Microscopic analysis revealed that, the above results is due to the formation of tribo-chemical film which existed as protective layer on sliding surface thus preventing metal to metal contacted each other, hence contributed to the favor of frictional reduction.
\end{abstract}

\section{Keywords}

bio-oil, applied loads, temperatures, tribological properties, coefficient of friction, volume wear loss, wear scar diameter, wear rate

\section{Introduction}

In the last decade, vast of interest was developed to use environment friendly biodegradable lubricant fluids [14]. Depletion of world petroleum reserves and uncertainty in petroleum supply also stimulated the investigation for environmental friendly alternative to mineral oils $[2,3]$. In this scenario, plant oils have gained great interest as lubricants over the last couple of decades. The conventional mineral based lubricant has been widely used in mechanical industry and it was proven to cause the ecological pollution due to some degree of toxicity. It is generally having high flammability characteristic that can give bad effect to our environment $[5,6]$. Previous study shows that, nearly to 12 million ton of lubricant waste dispose to environment. Therefore, due to awareness of environmental and health issues, some solution and steps had been taken by government in order to reduce and overcome the consumption of mineral-oil based lubricant [5] The conventional lubricant known as lubricating oil in industry which can cause serious pollutions to the environment and creates the greenhouse effect. Thus, to overcome these issues, vegetable oils has been introduced globally. A vegetable oil is extracted from a plant and has widely been used as a lubricant. The usage of vegetable oil as the lubricating oil industry was not a new idea and was introduced for many thousand years ago. Malaysia is one the largest producers and exporters palm oil in the world, accounting $11 \%$ of the world's oils and fat production and $27 \%$ of export trade oils and fats. Nowadays, around $2 \%$ of the base stocks are of plant oil origin [7, 8]. A biolubricants may be plant oil-based or derived from synthetic esters manufactured from modified renewable oils or from mineral oil-based products [9-11]. Biolubricants are generally considered as a lubricant with high biodegradability as well as low human and environmental toxicity [12]. A lubricant is classified as biodegradable if its percentages of degradation in a standard test exceeds a certain marked level.

In mechanical field, friction and wear was attributes by the tribological properties of the conventional oils since it 
can lead to the mechanical failures. Lubrication is one of the mechanism that being used to eliminates and minimize this failure. The presence of continuous lubricants thickness [13, 14] in the machines and engines mostly, is effective on the surface contact and gives benefit to the surface. The interaction between two surfaces will cause friction and lubricant lubricated to prevent from metals part produces wear and friction and then produced excessive heat. Many problems occur between metalon-metal contact due to wear and friction mechanism. Previous researcher found that wear and friction primarily changes with load [15-18], temperature [19], surface roughness [20, 21] type of material or mating component [22] and environmental. The study in understanding the wear mechanism in different parameter played important role in identifying new solutions and findings to overcome to these particular problem. Among of these factors, speed and load are major factors that give high impact to the friction force and wear value.

Banana skin had been referred as slipping tools [23]. Coefficient of frictions, COF under an epicarp of banana skin, on the floor material is much lower to the value of common materials and similar to the well-lubricated surface. The lubricating effect of banana skin was contributed by the existence of follicular gel, which is sized about a few micrometers [23]. Another study found that, percentages of extraction yields of bio oil from the peel waste of banana species were influenced by the existence of follicular gel [24]. In their study, the follicular gel was analyses using scanning electron microscopes and they concluded that, the polysaccharide follicular gel is a major key element in formation of oil [24]. Moreover, Rosenthal et al., [25] and Foidl and Eder [26] discussed that for plant materials, the oil constituents are trapped in the meshwork of proteins and cellulose/ hemicellulose or also known as polysaccharides which formed a bunch of follicular gel that related to polysaccharide follicular [25-27]. Hamid et al., [28] investigated the effects of banana peel of Cavendish species as a natural additive in paraffin oil. The tribological properties of the specimens were evaluated using four-ball tester. Their findings revealed that, coefficient of friction, $\mu$ and wear significantly reduced at high load, temperature and speed. At $100^{\circ} \mathrm{C}$, the load of 500 and 1000 $\mathrm{N}$, the COF value reduces from 0.1163 to 0.1012 and 0.1235 to 0.1174 respectively. At the same condition, wear scar diameter was found to decrease from $4.81 \times 10^{-4} \mathrm{~mm}^{3}$ to $2.33 \times 10^{-4} \mathrm{~mm}^{3}$ and $4.99 \times 10^{-4} \mathrm{~mm}^{3}$ to $2.75 \times 10^{-4} \mathrm{~mm}^{3}$ at 500 and $1000 \mathrm{rpm}$ respectively.
However, the research work on the study of tribological behavior of bio-oil extracted from banana peel wastes of Musa Aluminata Balbisiana (MBS) has not been reported in the literature. Hence, this paper intends to provide information's on tribological behavior of bio-oil extracted from banana peel wastes of Musa Aluminata Balbisiana (MBS) with specific aim to study the effects of applied loads and temperatures on COF, volume wears loss $\left(V_{\text {loss }}\right)$, wear scar diameter (WSD), and wear rate $(W s)$.

\section{Methodology}

2.1 Materials and apparatus

In this study, the MBS oil was obtained using Soxhlet extraction method. The peel waste of MBS was crushed into smaller sizes and dried using and was ground using commercial blender. The ground dried MBS powder was soaked into $n$-hexane (as solvent) for 7 hours. The extraction process was carried out at the boiling points of $n$-hexane solvent in order to achieve a maximum oil yield. The oil was concentrated using rotary evaporator under reduced pressures to remove the excess solvent and pale brownish oil was obtained. The pale brownish oil of MBS oil was subjected to physical, physiochemical and fatty acids analysis before further used in tribological analysis. The physical and physiochemical properties of MBS oil was tabulated in Tables 1 and Table 2 was depicted the fatty acids profile of MBS oil.

In the present investigation, pin on disk had been used to study both wear and coefficient of friction (Fig. 1). A pin was held firmly against a rotating disc connected to a certain dead

Table 1 Physical and physiochemical properties of MBS oil

\begin{tabular}{ll}
\hline Properties & Value \\
\hline Extraction Recovery, (\%) & 42.38 \\
Colour & Pale brownish \\
Density at $40{ }^{\circ} \mathrm{C}, \mathrm{kg} / \mathrm{m}^{3}$ & 0.8502 \\
Specific Gravity & 0.8536 \\
Kinematic Viscosity $\left(\right.$ at $\left.40^{\circ} \mathrm{C}\right),(\mathrm{cSt})$ & 3.29 \\
Total Acid Number $(\mathrm{mg} \mathrm{KOH} / \mathrm{g})$ & 0.52 \\
Free Fatty Acids, FFAs & 2.64 \\
\hline
\end{tabular}

Table 2 Fatty acids profile of MBS oil

\begin{tabular}{lll}
\hline Fatty Acids & Structures* & \% Distribution \\
\hline Butyric Acid & C4:0 & 10 \\
Caproic Acid & C6:0 & 36 \\
Myristic Acid & C14: 1 & 6 \\
Ginkgolic acid & C15: 1 & 34 \\
Gondoic Acid & C20:1 & 4 \\
Methyl Nerranoic Acid & C24: 1 & 2 \\
Gamma-Linolenic Acid & C18: 3N6 & 2 \\
cis-8,11,14-Eicosatrienoic acid & C20:3N6 & 2 \\
\hline
\end{tabular}

\footnotetext{
* Carbon number with 'zero' double bonds are saturated fatty acids, with 'one' double bonds are monounsaturated fatty acids and with 'two' or
} 'three' double bonds are polyunsaturated fatty acids. 


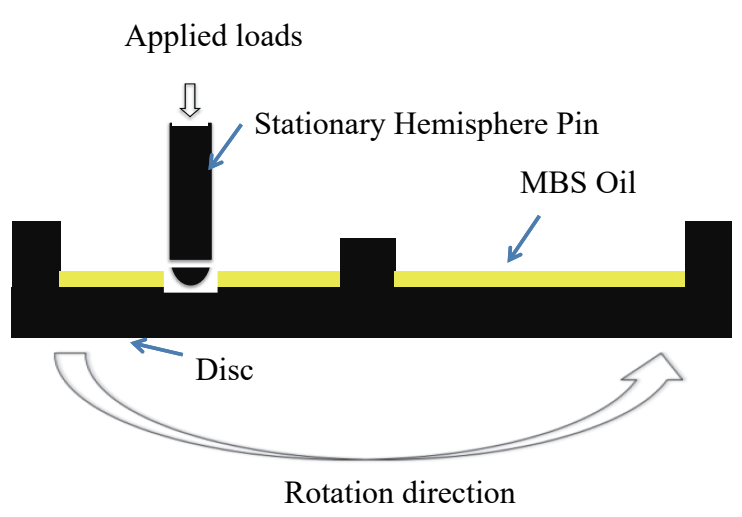

Fig. 1 Pin on disc experimental arrangement

weight with a beam and two pulleys. MBS oil was placed on the disc surface. The wear track was adjusted by loosening the sliding plate at $40 \mathrm{~mm}$ and fixed during the experiment conducted. During the experiments, new pins were used for each run and were cleaned with acetone to remove the impurities. The winducom 2008 software was used to record the data from the pin on disc machine.

\subsection{Experimental procedures}

In this study, the tribological testing was performed according to the ASTM G99-05 standard under wet sliding conditions at different temperatures and applied loads. The detail of pin and disc properties is listed in Table 3 and the operating condition for tribological properties of MBS oil is tabulated in Table 4 below. A constant sliding speed (50 RPM), wear track diameter $(314 \mathrm{~m})$ sliding times (50 minutes) were applied along the experiments. The pin was heated using an external heat resource where a thermocouple was placed on the edge of the counterpart pin. An infrared thermometer (Extech 42580) was used to measure the temperature before the test began. During the experiment, a hemispherical pin was clamped against the rotating disc and $2 \mathrm{ml}$ of MBS oil was dropped on the surfaces. Both of the surfaces of the hemispherical pins and disc were made parallel to ensure their maximum contact. The surfaces morphology and wear scar analysis of the pin was then observed using scanning electron microscopes, SEM.

Table 3 Hemisphere pin and disc properties

\begin{tabular}{lll}
\hline Properties & Disc & Hemisphere Pin \\
\hline Materials & En31 Steel & Steel \\
Surface Roughness, Ra & $0.03 \mu \mathrm{m}$ & $0.08 \mu \mathrm{m}$ \\
Hardness & $64 \mathrm{HRC}$ & $62 \mathrm{HRC}$ \\
Diameter & - & $5 \mathrm{~mm}$ \\
\hline
\end{tabular}

Table 4 Operating condition for tribological properties of MBS oil

\begin{tabular}{ll}
\hline Test Parameter & Value \\
\hline Applied Loads $(\mathrm{N})$ & $20,40,60,80,100$ \\
Temperatures $\left({ }^{\circ} \mathrm{C}\right)$ & $27,40,100$ \\
\hline
\end{tabular}

2.3 Coefficient of friction (COF) and specific wear rate The value of coefficient of Friction (COF) and Wear Rate Evaluation were calculated based on Eqs. 1, 2 and 3 below:

$$
\begin{aligned}
& C O F=\frac{F}{W} \\
& W S=\frac{V l o s s}{W x L} \\
& V_{\text {loss }}=\pi \mathrm{d}^{4} / 64 \mathrm{R}
\end{aligned}
$$

[Ws is the specific wear rate $\left(\mathrm{mm}^{3} / \mathrm{Nm}\right) ; W$ is the applied load $(\mathrm{N}) ; L$ is the sliding distance $(\mathrm{m}) ; V_{\text {loss }}=$ wear volume losses of the pins; $d$ = wear scar diameter in unit of meter; $R=$ radius of the pin in unit of meter $(0.00149 \mathrm{~m})]$.

\subsection{Surface morphology analysis}

Morphological characterization of the pin surface was carried out using SEM which produces images of a sample by scanning it with a focused beam of electrons (JEOL, JSM 840). The electrons in the beam interact with the sample producing various signals that can be used to obtain information about the surface topography and composition (EDX). The surfaces of all the samples were coated with a thin film of platinum using Polaron SC 7640 Sputter in order to improve the conductivity and avoid electron-charging effects during analysis.

\section{Results and discussion}

3.1 Effect of applied loads on friction coefficient, COF at various temperature

Lower coefficient of friction is desirable for proper functioning of equipment's and reduces the energy loss. In wide ranges of automotive applications, most of the researchers agreed that, the acceptable ranges of COF is between $0.05-0.14$ [12, 29-36]. Based on Fig. 2, the COF value of MBS oil at steady state is range from 0.06 to 0.40 . From Fig. 2, it clearly shows that, MBS oil exhibited a similar pattern of $\mathrm{COF}$ values at all the tested temperatures. As the load increased from $20 \mathrm{~N}$ to $40 \mathrm{~N}$, the $\mathrm{COF}$ value is increased (Phase I). However, the COF values start to decrease from $40 \mathrm{~N}$ to $80 \mathrm{~N}$ (Phase II) and from $80 \mathrm{~N}$ to $100 \mathrm{~N}$, the COF value showed an increasing pattern (Phase III).

As depicted in Phase I (Fig. 2), the COF values showed an increasing gradually pattern as the applied load increased.

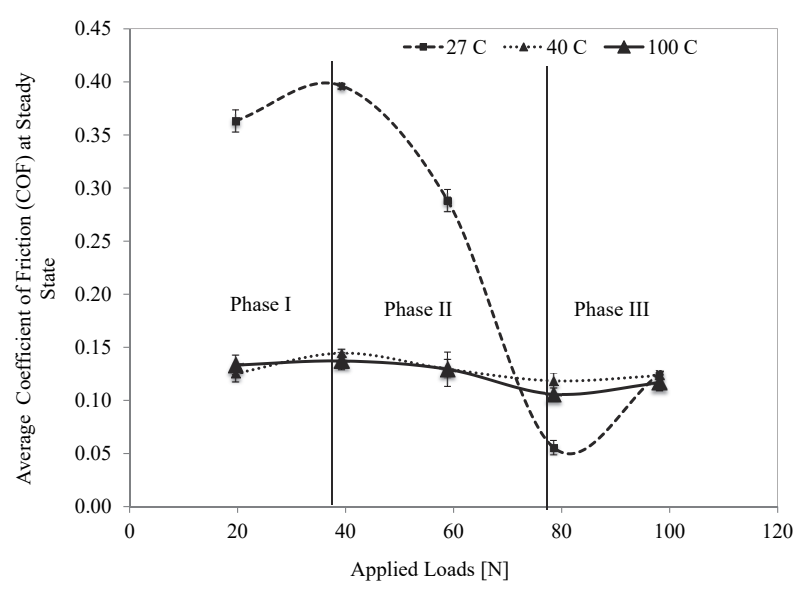

Fig. 2 Average COF at steady state different applied loads [N] at $27^{\circ} \mathrm{C}, 40^{\circ} \mathrm{C}$ and $100^{\circ} \mathrm{C}$ 
There were clearly observed that, a rapid increment on COF at the beginning of the test due to the running in period. At this period, a high contact pressure between two surfaces caused wear and plastic deformations of the peak surface, the profile contact of the surface is gradually improved and the surface pressure, and COF decreases so it enters a stable wear stage [37]. The increased of the load hence will produce higher stress concentration in localized region. Therefore, this situation can lead to localized plastic deformation and continued by initiation and abrupt propagation of crack which resultant in the spall formation [37, 38]. Moreover, at this phase, the fluid protective film was still in early stage of development process.

At phase II (Fig. 2), the graph showed rapid and gradually decrement in COF as the applied loads was increased. At this region, a layer of protective fluid tribo-chemical film was formed on sliding surface thus preventing metal to metal contacted each other [29]. Furthermore, a tribo-chemical reaction may occur between fatty acids composition in MBS oil with the disc surface, hence may have resulted in the formation of metallic soap layer, and fluid protective layer that contributed to the favor of frictional reduction [29, 39, 40]. As shown in Fig. 3, steel (pin) was believed to exist as contacting surface while steel (disc) acts as opposing contacting surface. The magnitudes of COF indicate that the lubrication regime occurred in the rubbing zone is boundary lubrication. Moreover, at this phase, the fluid protective film was fully developed with functioned to protect the contacted surface. At all the tested temperatures of the load of $80 \mathrm{~N}$, it shows the greatest ability to retain its properties without the breakdown of the lubrication film. In this study, at higher load $(80 \mathrm{~N})$, the lubricating film thickness become thinner than some of the asperities present in the boundary lubrication. However, the asperities are covered by the long chain fatty acids and the ester of bio lubricant, which are known as surface-active materials [40].

The presence of adsorption of polar molecules such as long chain fatty acids and ester in bio lubricants act as efficient barrier for protective sliding surface contact and friction surface lead to reduction in COF. In addition, the existences polar group of ester group also provides an affinity to metal surface and contributed to the formation of protective layer between metal surfaces [29, 41]. In other words, the polarity of the ester group creates a strong affinity to the metal by one end of the molecules and it's allowed a nonpolar hydrocarbon to extend out and provides a barrier between surfaces [29].

Moreover, the presence of carbonyl group in MBS oil was believed to be chemically and physically adsorbed onto the steel or metal surface [42-49]. The adsorption therefore provides a prevention of direct contact between frictional pairs due to the formation of orderly and closely packed molecular multi layers. A schematic representation of chemical adsorption of fatty acids

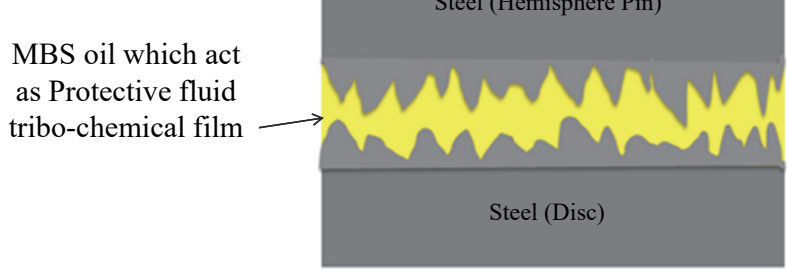

Fig. 3 A schematic representation of the protective fluid tribo-chemical's film and its corresponding contact mechanism in pin on disc under lubrication of MBS oil

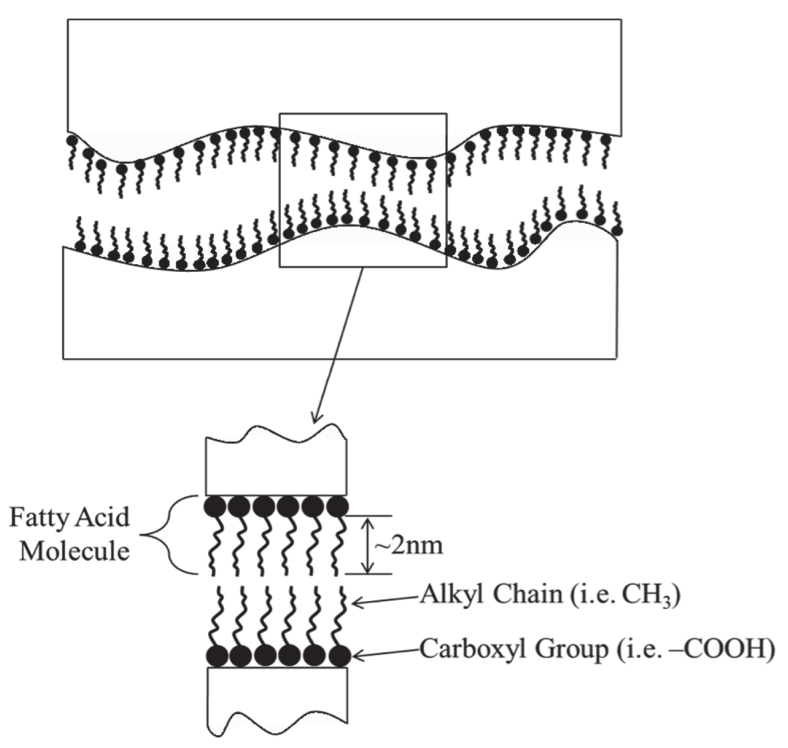

Fig. 4 Schematic representation of the chemical adsorption of fatty-acid molecules in MBS oils on the surface during friction

molecules of MBS oil on surfaces during friction is shown in Fig. 4 below [39, 43]. Furthermore, fatty acids molecules which known as corrosive component, was believed can cause the corrosion and material removal of fractional pairs. The higher amount of acidic substances will lead to the serious corrosive wear and the highest wear lost [41].

At Phase III, the COF values showed an abrupt and increasing pattern from $80 \mathrm{~N}$ to $100 \mathrm{~N}$. At this phase however, it was believed that, the COF values start to increase as the ability of MBS oil to provide a tribo-chemical protective layers failed to retain. This region was contributed by the heat generated, thus led to the increasing of COF. As the load increased, the more heat produced due to the pressured on the surfaces, hence could cause to the vaporization, degradation, cleavage and chemical oxidation of some of the chemical compounds in MBS oil and this could lead in the failure of the MBS oil in providing a protective layer $[37,41]$. This condition hence could be the reason for the increasing COF value along with the increasing in applied load and temperatures of the experiments.

3.2 Effect of applied loads on wear scar diameter (WSD) and wear rate, Ws at various temperatures

Wear is the progressive loss material due to interacting surfaces in relative motion. Friction and wear are related both are phenomenon of a solid contact between moving mating components. Figure 5 showed WSD $(\mu \mathrm{m})$ at different loads and temperatures. It was observed that, for all the operating temperatures, there were shown a similar pattern of curves plotted. The wear dominated by the pin is increasing from $20 \mathrm{~N}$ to $40 \mathrm{~N}$. However, the decreasing pattern of WSD was started to observe from $20 \mathrm{~N}$ to $80 \mathrm{~N}$ and it shows an increasing trend after $80 \mathrm{~N}$ to $100 \mathrm{~N}$. The lowest WSD was recorded at the 80 $\mathrm{N}$ with the values of $501.143 \mu \mathrm{m}, 250.912 \mu \mathrm{m}$ and $331.103 \mu \mathrm{m}$ respectively meanwhile, the highest was observed at the load of $100 \mathrm{~N}$ with the values of $1530 \mu \mathrm{m}, 915.926 \mu \mathrm{m}$ and $1166 \mu \mathrm{m}$ respectively for all the tested temperatures. The lowest WSD at the $80 \mathrm{~N}$ for all the tested temperatures was influenced by the formation of preventive layer of tribo-chemical film.

A COF values and WSD play vital roles in evaluating the 


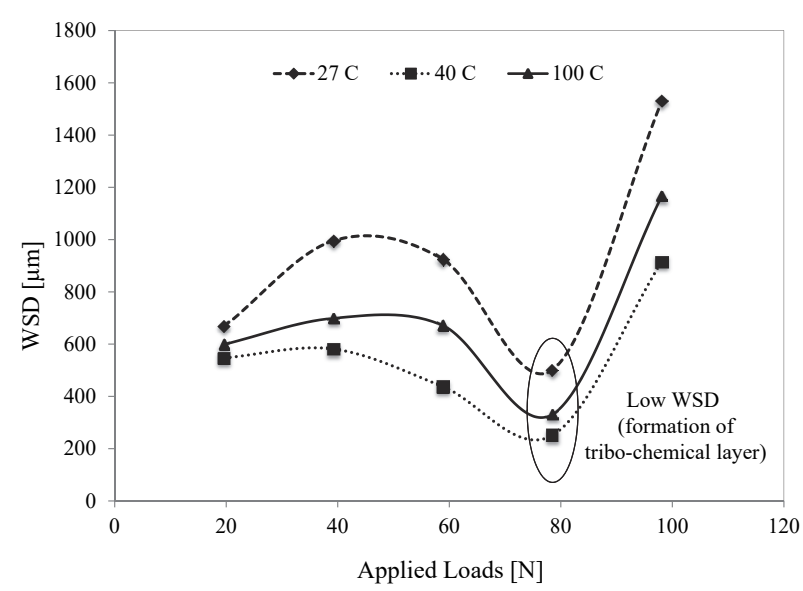

Fig. 5 WSD $(\mu \mathrm{m})$ at different loads

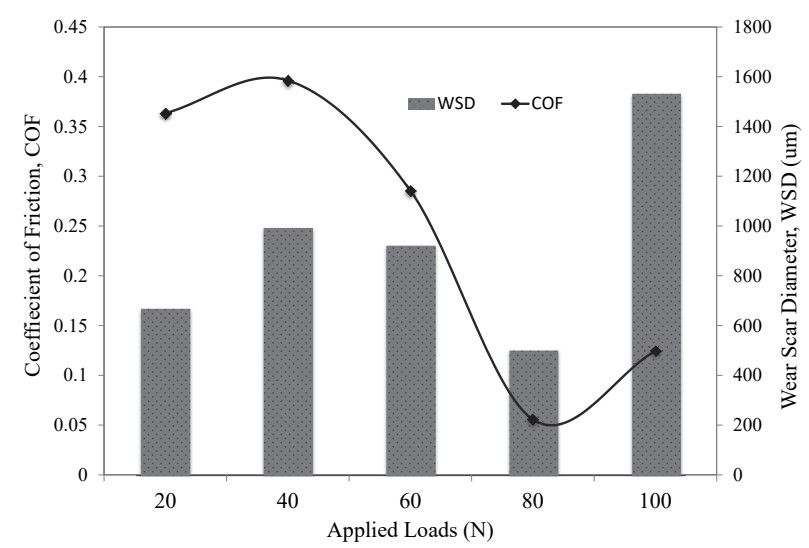

Fig. 6 The relationship of $\mathrm{COF}$ values and wear scar diameter at temperature of $27^{\circ} \mathrm{C}$

tribological properties. The relationship of COF and WSD of MBS oil at different loads and temperatures was depicted in Figs. 7, 8 and 9. Bowder and Tabor [50] discussed that, since a friction is caused by somewhat different set of mechanism than wear, the result from experiment might be low wear and high friction and vice versa. This behavior might due to the increased shear strength of the adsorbed oil on the surface of the balls and effected chemical attack on the surface by the fatty acid compositions, which present in vegetable oil.

Figure 9 below shows Specific Wear rate of MBS oil versus various load at operating temperatures of $27^{\circ} \mathrm{C}, 40^{\circ} \mathrm{C}$ and $100^{\circ} \mathrm{C}$. A low wear rate $\left(0.0084 \times 10^{-15} \mathrm{~mm}^{3} / \mathrm{Nmm}, 0.005 \times 10^{-15} \mathrm{~mm}^{3} /\right.$ $\left.\mathrm{Nmm}, 0.016 \times 10^{-15} \mathrm{~mm}^{3} / \mathrm{Nmm}\right)$ and volume wear loss $(2.08 \times$ $\left.10^{-12} \mathrm{~m}^{3}, 0.13 \times 10^{-12} \mathrm{~m}^{3}, 0.40 \times 10^{-12} \mathrm{~m}^{3}\right)$ was observed at the load of $80 \mathrm{~N}$ for all the tested temperatures respectively. These results was attributed by the formation of tribo-chemical layers which role as protective layer to prevent spherical pin metal and disc metal contacting each others. A high wear rates (5.858 $\times 10^{-15} \mathrm{~mm}^{3} / \mathrm{Nmm}, 0.753 \times 10^{-15} \mathrm{~mm}^{3} / \mathrm{Nmm}$ and $1.976 \times 10^{-15}$ $\left.\mathrm{mm}^{3} / \mathrm{Nmm}\right)$ and wear volume losses $\left(18.050 \times 10^{-12} \mathrm{~m}^{3}, 23.190\right.$ $10^{-12} \mathrm{~m}^{3}$ and $60.89010^{-12} \mathrm{~m}^{3}$ ) were observed at load of $100 \mathrm{~N}$ at all the tested temperatures respectively. It is believed that the wear particles of the pin may get locked between sliding surface and/or transferred and embedded to mated discs and subsequently gave many damages to the pin. This condition led to the adhesive action and promoted three bodies, which should

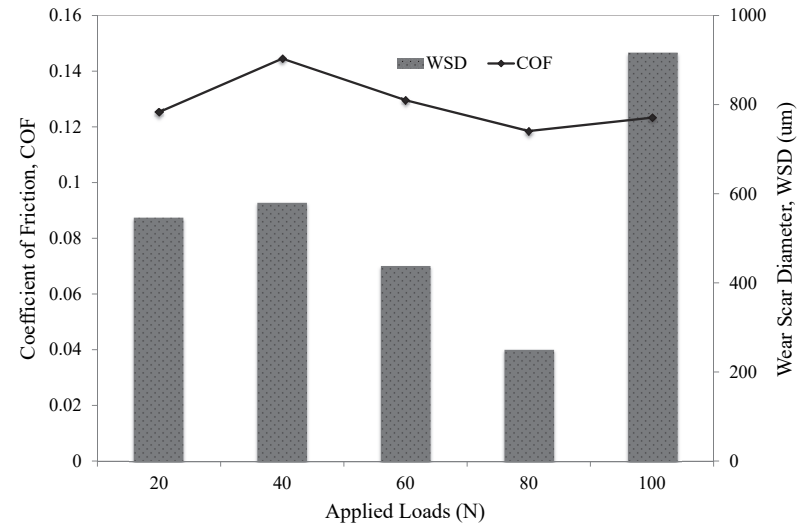

Fig. 7 The relationship of COF values and wear scar diameter at temperature of $40^{\circ} \mathrm{C}$

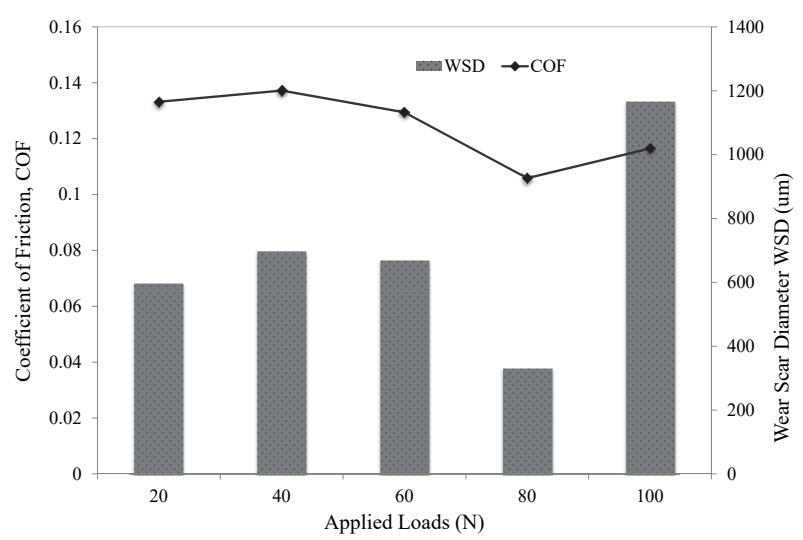

Fig. 8 The relationship of COF values and wear scar diameter at temperature of $100^{\circ} \mathrm{C}$

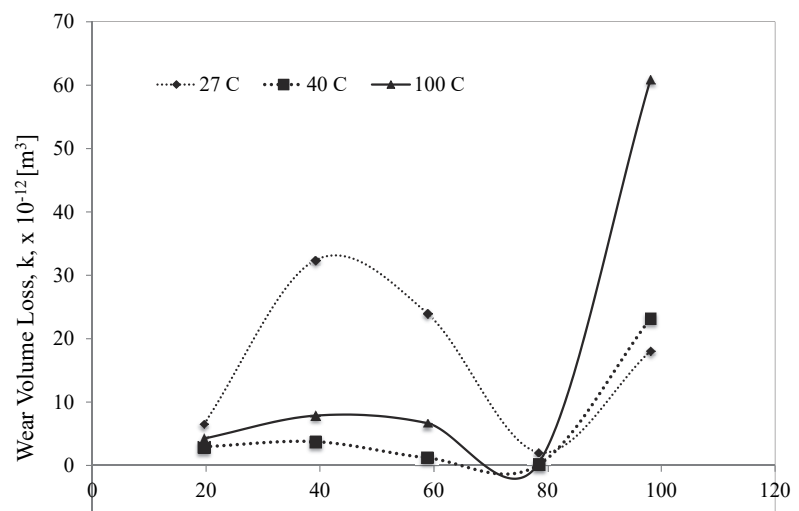

Applied Loads [N]

Fig. 9 Specific wear rate and wear volume loss of MBs oil at various applied loads at $27^{\circ} \mathrm{C}, 40^{\circ} \mathrm{C}$ and $100^{\circ} \mathrm{C}$

enhance volume loss in wear $[16,51]$. This wear debris from pin and disc will trapped at interface and thus will act as an extra layer to aid the motion of the pin and disc hence, it will decrease the friction coefficient as the load applied is increased [18]. A good lubricants achieved when its able to reduce and minimize the volume loss of the materials. It is believed that the wear particles of the pin may get locked between sliding surface and/ 
or transferred and embedded to mated discs and subsequently gave many damages to the pin can caused roughening effect on the pin [52]. This condition might lead to the adhesive action and promoted three bodies, which should enhance volume loss $[16,51,52]$. This wear debris from pin and disc was believed to trap at interface and serves as an extra layer to aid the motion of the pin and disc hence, it contributed to decrease the friction coefficient as the load applied is increased [18]. It also believed that the high temperature generated at interface also influence the wear dominated by the pin.

3.3 Comparison of coefficient of friction with other study

The coefficient of friction of MBS oil in this study were compared with other types of oil including vegetable oils and commercial engine oil. Table 5 summarised the compilation of the coefficients of friction from the literature review.

\section{Conclusion}

The investigation on tribological behavior of MBS oil was successfully performed using pin on disc tribometer. Qualitative and quantitative analysis were performed and it revealed that, at the load of $80 \mathrm{~N}$, the COF value, wear scar diameter (WSD), specific wear rate $(W s)$ and volume wear loss are much lower due the formation of tribo-chemical film. The finding from this study might contribute to the sustainable development of the biolubricant fields. In addition, this study shows that, MBS oil, which extracted from the waste of banana peels, has a promising future to replace a mineral oil based lubricants.

\section{Acknowledgement}

The authors would like to acknowledge the Faculty of Mechanical Engineering, Universiti Teknikal Malaysia Melaka for financial support through research grant no. FRGS/2018/ FKM-CARE/F00366 and the Ministry of Higher Educations (MOHE), which made this study possible.

\section{References}

[1] Singh, C. P. and Chhibber, V. K., "Chemical Modification in Keranja Oil for Biolubricant," Industry Research Article, 3, 3, 2013, 117-122.

[2] Rudnick, L. R. and Erhan, S. Z., "In Synthethics, Mineral Oils and Bio-Based Lubricant: Chemistry and Applications," Ed. L. R. Rudnick, Boca Raton, FL: CRC Press, 2006.

[3] Adhvaryu, L. A. and Erhan, S. Z., "Synthesis of Novel Alkoxylated Triacylglycerols and Their Lubricants Base Oil Properties," Industrial Crops and Products, 21, 2005, 113-119.

[4] Erhan, S. Z., Adhvaryu, A. and Sharma, B. K., "Chemically Functionalized Vegetable Oils," Chemical Industies, 111, 2006, 361388.

[5] Nuraliza, N., Syahrullail, S. and Faizal, M. H., “Tribological Properties of Aluminum Lubricated with Palm Olein at Different Load Using Pin-on-Disk Machine," Jurnal Tribologi, 9, 2016, 45-59.

[6] Husnawan, M., Saifullah, M. G. and Masjuki, H. H., “Development of Friction Force Model for Mineral Oil Basestock Containing Palm Olein and Antiwear Additive," Tribology International, 40, 1, 2007, 74-81.

[7] Salimon, J., Salih, N. and Yousif, F., "Biolubricants: Raw Materials, Chemical Modifications and Environmental Benefits," European Journal of Lipid Science and Technology, 112, 5, 2010, 519-530.

[8] Erhan, S. Z. and Adhvaryu, A., "Chemically Functionalized Vegetable Oils," Chemical Industries, 111, 2002, 361-388.

[9] Levizzari, A., Voglino, M. and Volpi, P., "Environmental and Economic Impacts of Re-Fined Products: A Life Cycle Analysis," Proceedings of the 6th International LFE Congress, Brussel, 1999

[10] Kumar, N. and Chauhan, S., "Analysis of Tribological Performance of Biodiesel," Proceedings of the Institution of Mechanical

Table 5 Compilation of the coefficient of friction obtained from previous and this study

\begin{tabular}{|c|c|c|c|c|c|}
\hline Lubricant & Load $(\mathrm{N})$ & Temp. $\left({ }^{\circ} \mathrm{C}\right)$ & $\mathrm{COF}$ & Apparatus & Reference \\
\hline SAE $20 W 50$ & 10 & - & 0.112 & Block-on-disc & \multirow{3}{*}[53]{} \\
\hline SAE $20 W 40$ & 10 & - & 0.086 & Block-on-disc & \\
\hline SAE $15 W 40$ & 10 & - & 0.093 & Block-on-disc & \\
\hline Paraffin Oil & 392 & 100 & 0.077 & Four-ball & \multirow{2}{*}{ [29] } \\
\hline Calophyllum Inophyllum & 392 & 100 & 0.065 & Four-ball & \\
\hline Trimethylolpropane & 392 & 27 & 0.1 & Four-ball & {$[30]$} \\
\hline Chemically Modified Rapeseed Oil & 80 & 60 & 0.082 & HFR test rig & [31] \\
\hline Sunflower Oil & 10 & 50 & 0.049 & HFR test rig & \multirow{2}{*}{ [32] } \\
\hline Soybean Oil & 10 & 50 & 0.05 & HFR test rig & \\
\hline Coconut Oil & 10 & - & 0.09 & Block-on-disc & \multirow{2}{*}[53]{} \\
\hline Soybean Oil & 10 & - & 0.112 & Block-on-disc & \\
\hline Sunflower Oil & 50 & 22 & 0.136 & Pin-on-disc & {$[54]$} \\
\hline Musa Aluminata Balbisiana Oil & 20 & 100 & 0.132 & Pin-on-disc & \multirow{3}{*}{ Present Study } \\
\hline Musa Aluminata Balbisiana Oil & 80 & 100 & 0.105 & Pin-on-disc & \\
\hline Musa Aluminata Balbisiana Oil & 100 & 100 & 0.118 & Pin-on-disc & \\
\hline
\end{tabular}

* HFC: high frequency reciprocating 
Engineers, Part J: Journal of Engineering Tribology, 228, 7, 2014, 797807.

[11] Dorinson, A. and Ludema, K. C., "Mechanics and Chemistry in Lubrication," Elsevier, Amsterdam, 1985.

[12] Mobarak, H. M., Mohamad, E. N., Masjuki, H. H., Kalam, M. A., Al Mahmud, K. A. H., Habibullah, M. and Ashraful, A. M., "The Prospects of Biolubricants as Alternatives in Automotive Applications," Renewable and Sustainable Energy Reviews, 33, 2014, 34-43.

[13] Fervel, V., Mischler, S. and Landolt, D., “Lubricating Properties of Cotton Transfer Films Studied with a Pin-on-Disc Apparatus," Wear, 254, 5-6, 2003, 492-500.

[14] Hamrock, B. J., Schmid, S. R. and Jacobson, B. O., "Fundamentals of Fluid Lubrication 2nd Edition," CRC Press, 2004.

[15] Syahrullail, S., Azmi, A. M., Sapawe, N. and Amir, K., "Wear Characterization of Aluminum Lubricated with Palm Olein at Different Normal Load," Applied Mechanics and Materials, 554, 2014, 401-405.

[16] Hisakado, T. and Hashizume, N., "Effects of Normal Loads on the Friction and Wear Properties of Metals and Ceramic against Cermet in Vacuum," Wear, 237, 1, 2000, 98-106.

[17] Ameen, H. A., Hassan, K. S. and Mubarak, E. M. M., “Effect of Loads, Sliding Speeds and Times on the Wear Rate for Different Materials," American Journal of Scientific and Industrial Research, 2, 1, 2011, 99-106.

[18] Chowdhury, M. A., Khalil, M. K., Nuruzzaman, D. M. and Rahaman, M. L., "The Effect of Sliding Speed and Normal Load on Friction and Wear Property of Aluminum," International Journal of Mechanical \& Mechatronics Engineering, 11, 1, 2011, 53-57.

[19] Al-Araji, N. and Sarhan, H., "Effect of Temperature on Sliding Wear Mechanism under Lubrication Conditions," International Journal of Engineering, 5, 2, 2011, 176-184.

[20] Hisakado, T., Miyazaki, K., Kameta, A. and Negishi, S., "Effects of Surface Roughness of Roll Metal Pins on Their Friction and Wear Characteristics," Wear, 239, 1, 2000, 69-76.

[21] Wang, W. Z., Chen, H., Hu, Y. Z. and Wang, H., "Effect of Surface Roughness Parameters on Mixed Lubrication Characteristics," Tribology International, 39, 6, 2006, 522- 527.

[22] Bressan, J. D., Daros, D. P., Sokolowski, A., Mesquita, R. A. and Barbosa, C. A., "Influence of Hardness on the Wear Resistance of 17-4 PH Stainless Steel Evaluated by the Pin-on-Disc Testing," Journal of Materials Processing Technology, 205, 1-3, 2008, 353-359.

[23] Mabuchi, K., Tanaka, K., Uchijima, D. and Sakai, R., "Frictional Coeffiction under Banana Skin," In Technical Session in the International Tribology Conference Hiroshima, 2012, 147-151.

[24] Hamid, H. A., Masripan, N. A. B., Hasan, R. B., Abdollah, M. F. B. and Omar, G. B., "Characterization of Raw and Ripen of Banana Peel Wastes and It's Oils Extraction Using Soxhlet Method," International Journal of Applied Chemistry, 12, 1, 2016, 1-5.

[25] Rosenthal, A., Pyle, D. L. and Niranjan, K., "Aqueous and Enzymatic Processes for Edible Oil Extraction," Enzyme and Microbial Technology, 19, 6, 1996, 402-420.

[26] Foidl, N. and Eder, P., "Agro Industrial Exploitation of Jatropha Curcus, In: Gubitz, G. M., MittelbachM, Trabi M. Editors. Bio-Fuels and Industrial Products from Jatropha Curcas. Graz: D bv-Verlag," 1997, 88-91.

[27] Rosenthal, A., Pyle, D. L., Niranjan, K., Gilmour, S. and Trinca, L., "Combined Effect of Operational Variables and Enzyme Activity on Aqueous Enzymatic Extraction of Oil and Protein from Soybean," Enzyme and Microbial Technology, 28, 6, 2001, 499-509.

[28] Hamid, A. H., Masripan, N. A. B., Basiron, J., Mustafa, M. M. B, Hasan, R., Abdollah, M. F. B. and Ismail, R., "Effect of Banana Peels as an Additive on the Tribological Proporties of Paraffin Oil," Jurnal
Teknologi, 77, 21, 2015, 73-77.

[29] Habibullah, H., Masjuki, H. H., Kalam, M. A, Gulzar, M., Arslan, A. and Zahid, R., "Tribological Characteristics of Calophyllum Inophyllum-Based TMP (Trimethylolpropane) Ester as EnergySaving and Biodegradable Lubricant," Tribology Transactions, 58, 6, 2015, 1002-1011.

[30] Zulkifli, N. W. M., Azman, S. S. N., Kalam, M. A., Masjuki, H. H., Yunus, R. and Gulzar, M., "Lubricity of Bio-Based Lubricant Derived from Different Chemically Modified Fatty Acid Methyl Ester," Tribology International, 93, Part B, 2016, 555-562.

[31] Arumugam, S. and Sriram, G., "Effect of Bio-Lubricant and Biodiesel-Contaminated Lubricant on Tribological Behavior of Cylinder Liner-Piston Ring Combination," Tribology Transactions, 55, 4, 2012, 438-445.

[32] Alves, S. M., Barros, B. S., Trajano, M. F., Ribeiro, K. S. B. and Moura, E., "Tribological Behavior of Vegetable Oil-Based Lubricants with Nanoparticles of Oxides in Boundary Lubrication Conditions," Tribology International, 65, 2013, 28-36.

[33] Jain, A. K. and Suhane, A., "Capability of Biolubricants as Alternative Lubricant in Industrial and Maintenance Applications," International Journal of Current Engineering and Technology, 3, 1, 2013, 179-183.

[34] Bekal, S. and Bhat, N. R., "Bio-Lubricant as an Alternative to Mineral Oil for a CI Engine-An Experimental Investigation with Pongamia Oil as a Lubricant," Energy Sources, Part A: Recovery, Utilization, and Environmental Effects, 34, 11, 2012, 1016-1026.

[35] Masjuki, H. H., Maleque, M. A., Kubo, A. and Nonaka, T., "Palm Oil and Mineral Oil Based Lubricants - Their Tribological and Emission Performance," Tribology International, 32, 6, 1999, 305-314.

[36] Asadauskas, S., Perez, J. M. and Duda, J. L., "Lubrication Properties of Castor Oil - Potential Basestock for Biodegradable Lubricants," Lubrication Engineering, 53, 12, 1997, 35-40.

[37] Zulkifli, N. W. M., Kalam, M. A., Masjuki, H. H. and Yunus, R., “Experimental Analysis of Tribological Properties of Biolubricant with Nanoparticle Additive," Procedia Engineering, 68, 2013, 152157.

[38] Al-Bukhaiti, M. A., Al-Hatab, K. A. and Gabbert, U., "The Influence af High Contact Stresses and Lubricant Type an the Rolling Contact Fatigue Life and Failure Mode of Aisi 52100 Steel Balls," Emirates Journal for Engineering Research, 16, 1, 2011, 9-22.

[39] Tang, J., Ding, Q., Zhang, G. and Hu, L., "The Influence of Total Acid Number of Ester Oil in Tribological Behavior of DLC Contact," Tribology Transactions, 58, 5, 2015, 849-858.

[40] Shahabuddin, M., Masjuki, H. H., Kalam, M. A., Bhuiya, M. M. K. and Mehat, H., "Comparative Tribological Investigation of BioLubricant Formulated from a Non-Edible Oil Source (Jatropha Oil)," Industrial Crops and Products, 47, 2013, 323-330.

[41] Xu, Y., Hu, X., Yuan, K., Zhu, G. and Wang, W., "Friction and Wear Behaviors of Catalytic Methylesterified Bio-Oil," Tribology International, 71, 2014, 168-174.

[42] Simic, R., Kalin, M., Hirayama, T., Korelis, P. and Geue, T., "Fatty Acid Adsorption on Several DLC Coatings Studied by Neutron Reflectometry," Tribology Letters, 53, 1, 2014, 199-206.

[43] Simic, R. and Kalin, M., "Comparison of Alcohol and Fatty Acid Adsorption on Hydrogenated DLC Coatings Studied by AFM and Tribological Tests," Strojniski Vestnik-Journal of Mechanical Engineering, 59, 12, 2013, 707-718.

[44] Simic, R. and Kalin, M., "Adsorption Mechanisms for Fatty Acids on DLC and Steel Studied by AFM and Tribological Experiments," Applied Surface Science, 283, 2013, 460-470.

[45] Kalin, M., Simic, R., Hirayama, T., Geue, T. and Korelis, P., "Neutron-Reflectometry Study of Alcohol Adsorption on Various DLC Coatings," Applied Surface Science, 288, 2014, 405-410. 
[46] Kalin, M. and Simic, R., "Atomic Force Microscopy and Tribology Study of the Adsorption of Alcohols on Diamond-Like Carbon Coatings and Steel," Applied Surface Science, 271, 2013, 317-328.

[47] Makowski, S., Weihnacht, V., Schaller, F. and Leson, A., "UltraLow Friction of Biodiesel Lubricated Ta-C Coatings," Tribology International, 71, 2014, 120-124.

[48] Habchi, W., Matta, C., Joly-Pottuz, L., De Barros, M. I., Martin, J. M. and Vergne, P., "Full Film, Boundary Lubrication and Tribochemistry in Steel Circular Contacts Lubricated with Glycerol," Tribology Letters, 42, 3, 2011, 351-358.

[49] Matta, C., Bouchet, M. I. D. B., Le-Mogne, T., Vachet, B., Martin, J. M. and Sagawa, T., "Tribochemistry of Tetrahedral Hydrogen-Free Amorphous Carbon Coatings in the Presence of OH-Containing Lubricants," Lubrication Science, 20, 2, 2008, 137-149.

[50] Bowden, F. P. and Tabor, D., "The Nature of Metallic Wear, the Friction and Lubrication of Solids," Oxford Classic Texts, New York:
Oxford University Press, 2001, 285-298

[51] Menezes, P. L., Kishore, M. and Kailas, S. V., “Effect of Surface Roughness Parameters and Surface Texture on Friction and Transfer Layer Formation in Tin-Steel Tribo-System," Journal of Materials Processing Technology, 208, 1-3, 2008, 372-382.

[52] Mat Tahir, N. A., Abdollah, M. F. B., Hassan, R. and Amiruddin, H., "The Effect of Temperature on the Tribological Properties of Palm Kernel Activated Carbon-Epoxy Composite," Triboloy Online, 10, 6 , 2015, 428-433.

[53] Stojilković, M. and Kolb, M., "Tribological Properties of Biodegradable Universal Tractor Transmission Oil," Tribology in Industry, 38, 2, 2016, 229-234.

[54] Zhao, C., Jiao, Y., Chen, Y. K. and Ren, G., "The Tribological Properties of Zinc Borate Ultrafine Powder as a Lubricant Additive in Sunflower Oil," Tribology Transactions, 57, 3, 2014, 425-434. appropriate credit (with a link to the formal publication through the relevant DOI (Digital Object Identifier)) and provide a link to this license, and (iv) users acknowledge and agree that users and their use of such paper are not connected with, or sponsored, endorsed, or granted official status by the Licensor (i.e. Japanese Society of Tribologists). To view this license, go to https://creativecommons.org/licenses/by-nc-nd/4.0/. Be noted that the third-party materials in this article are not included in the Creative Commons license, if indicated on the material's credit line. The users must obtain the permission of the copyright holder and use the third-party materials in accordance with the rule specified by the copyright holder. 